\title{
Ismertetés: Tudatos jelenlét alapú intervenció az egyetemi hallgatók stressztűrő képességének fokozására (a „Tudatos hallgató” tanulmány): pragmatikus, randomizált, kontrollált vizsgálat
}

\author{
A mindfulness-based intervention to increase resilience to stress in \\ university students (the Mindful Student Study): a pragmatic \\ randomised controlled trial
}

Ismerteti: $\quad$ Fúzi Márta $\triangle$

Debreceni Egyetem, Népegészségügyi Kar, Megelőző Orvostani Intézet, Egészségfejlesztési Tanszék

Szerzők: Galante J, Dufour G, Vainre M, Wagner AP, Stochl J, Benton A, Lathia N, Howarth E, Jones PB. Megjelenés: Lancet Public Health. 2018 Feb;3(2):e72-e81. doi: 10.1016/S2468-2667(17)30231-1.

Beküldve: 2018. 05. 09.

doi: $10.24365 /$ ef.v59i4.304

Kulcsszavak: mentális egészség, tudatos jelenlét, intervenció, iskolai egészségfejlesztés

Keywords: mental health, mindfulness, intervention, school health promotion

A Cambridge-i Egyetemen a 2015-2016-os tanévben készült pragmatikus vizsgálat során az egyetemi hallgatók stressztűrő képességének fokozását túzték ki célul. A felsőoktatásban tanuló hallgatók létszáma az Egyesült Királyságban folyamatosan növekszik, emellett ezt meghaladó módon, 2010 és 2015 között 50\%-kal nőtt a mentális egészséggel összefüggő egyetemi szolgáltatások hallgatói igénybevétele.

A pragmatikus, randomizált, kontrollált, intervenciós vizsgálat során egy nyolchetes, a tudatos jelenlét (mindfulness) módszerét alkalmazó kurzus (MSS, Mindful Student Study) hatékonyságát hasonlították össze a mentális egészséget támogató rutin módszerek igénybevételével.

A vizsgálat során randomizációval 616 hallgatót osztottak szét: egyik részük ( $n=307)$ a kontrollcsoportba került, ők hagyományos mentális egészségtámogatásban részesültek; a másik részük az intervenciós csoportot képezte ( $n=309)$, ezek a hallgatók a hagyományos mentális egészségtámogatás mellett részt vettek az MSS-kurzuson is.

Az MSS-kurzus csoportos készségfejlesztő foglalkozások formájában zajlott, nyolc héten át, heti egy alkalommal. Célja az általános jóllétérzés és a mentális ellenálló képesség fokozása volt, a csoportlétszám nem haladta meg a 30 főt. A 75-90 perces foglalkozásokon a csoporttagok a rugalmasság, önfelfedezés, önelfogadás és az önmegvalósítás gyakorlása mellett a meditáció képességének elsajátításával kaptak olyan eszközöket, amiket a tanulás, a döntéshozatal vagy a személyes kapcsolatok terén is tudtak hasznosítani. Az alkalmakon meditációs gyakorlatok, kérdések és reflexiók megbeszélése és interaktív gyakorlatok szerepeltek. A csoportfoglalkozásokon kívül otthoni gyakorlásra kérték a hallgatókat (pl. tudatos séta vagy tudatos étkezés). 
Az elsődleges kimeneti változó az önértékelt pszichés distressz volt, amelyet a CORE-OM (Clinical Outcomes in Routine Evaluation Outcome Measure) skála használatával mértek. A CORE-OM 34 kérdésből áll, és négy dimenzió mentén méri az aktuális pszichés distressz mértékét: szubjektív jóllét; problémák vagy tünetek; funkcionalitás az életben és rizikótényezők jelenléte. Az Egyesült Királyságban gyakran használják hallgatók felméréséhez is, a magasabb pont magasabb stressz-szintet jelent. A vizsgálat kezdetén felvett alaphelyzeti értékeket a vizsgaidőszakban mért értékekhez hasonlították, mivel ez a periódus általánosan a leginkább stresszel terhelt a hallgatók életében.

Emellett másodlagos eredményindikátorokat is alkalmaztak: például felmérték az adakozókészséget, vagy két héten keresztül naponta értékelték a hallgatók megküzdési stratégiáit (problémafókuszú vagy érzelmi alapú) a tanulmányaikkal kapcsolatban.

Az MSS-intervenció átlagosan -0,25 CORE-OMponttal, statisztikailag szignifikánsan ( $95 \%$ MT: -0,34 - -0,16; $p<0,0001)$ csökkentette a vizsgaidőszakban tapasztalt distresszérzést a zavaró tényezőkre (intervenció előtti pontszám, kor, nem, intervenció és a vizsgaidőszak között eltelt idő) történő korrekció után, a kontrollcsoporthoz viszonyítva. A beavatkozás hatáserősségét mérsékeltnek véleményezték ( $\beta=-0,44,95 \% \mathrm{MT}:-0,6-0,29$, $p<0,0001)$. Az eredmények gyakorlati hasznát úgy mérték, hogy a vizsgaidőszakban mért CORE-OMpontokat a kóros mértékú distressz klinikai referenciaértékéhez viszonyították. Az MSS-intervencióban részesült diákok körében egyharmaddal kisebb valószínűséggel tapasztaltak kóros mértékű distresszt (relatív kockázat: 0,65, 95\% MT: 0,53-0,8; $\mathrm{p}<0,0001)$. A minimálisan szükséges betegszám (number need to treet) 6 (95\% MT: 4-10) volt, azaz átlagosan hat résztvevő közül egynél sikerült megelőzni a klinikai szintű distressz kialakulását. Az adakozókészség (esélyhányados: 1,80, 95\% MT 1,22-2,66; $p=0,003$ ) az intervenciós csoportban nagyobb volt, azonban a napi megküzdési stratégiákban nem tapasztaltak különbséget.

A randomizált, kontrollált vizsgálat eredménye alapján a tudatos jelenlét alapú intervenciót a hallgatók által elfogadható, kivitelezhető és hatékony intervenciónak véleményezték, ami a mentális egészséget a népegészségügyi szempontból kiemelt oktatási környezetben képes javítani.

\section{TANULSÁGOK A HAZAI SZAKEMBEREK SZÁMÁRA}

A cikkben ismertetett tudatos jelenlét alapú csoportfoglalkozás jól beilleszthető az oktatási rendszerbe. A mentális egészséggel összefüggő szolgáltatásokkal szembeni negatív attitűd nem érvényesült ennek alkalmazása során, ezáltal olyan eszközt biztosíthat a fiatalok számára, amelynek használatával a stresszel szembeni ellenálló képességük fokozódik, így a mentális egészséget már fiatalkorban képes pozitív irányba befolyásolni, és megelőzni mentális betegségek kialakulását. 